\title{
Where is the Chinese Economy Going? A Forum on Contemporary Policy and Performance
}

\author{
Ross Garnaut, Lauren Johnston and Ligang Song*
}

\begin{abstract}
* Garnaut and Johnston: Melbourne Institute of Applied Economic and Social Research, The University of Melbourne, Victoria 3010 Australia; Song: Crawford School of Public Policy, The Australian National University, Australian Capital Territory 2600 Australia. Corresponding author: Garnaut, email <ross.garnaut@unimelb.edu.au>. We thank Shenglang Yang for his help with assembling the data used in this article.
\end{abstract}

\begin{abstract}
China adopted a new model of growth from 2011, requiring substantial structural change. This introductory article presents statistical evidence on progress so far. Change generally is in the required direction, but slow. There has been early but slow progress on re-orienting domestic towards consumption; substantial re-orientation from reliance on exports towards domestic demand; and rapid change at the margin in the energy mix towards low-emissions sources. Investment in human capital is proceeding rapidly along lines required by the new model. So far, productivity growth has been slow, raising questions about future progress.
\end{abstract}

\section{Introduction}

This policy forum explores progress on policy and structural change in China's new model of economic growth. It is drawn from papers prepared for the annual review of Chinese economic policy and performance undertaken by the Australian National University, University of Melbourne and Chinese Academy of Social Sciences.

The new model of growth has been an aspiration of Chinese state policy since 2011, and has been articulated in increasing detail since then (Song et al. 2017). The new model seeks to move the economy away from unprecedented heavy reliance on investment towards greater consumption; from manufacturing and heavy industry towards services; from increasing reliance on exports towards greater focus on domestic demand, while deepening integration into global markets for investment and technology; from increasing inequality in the distribution of incomes towards greater equity; from large pressure on Chinese 
and global natural systems towards environmental sustainability; and more generally towards greater use of domestic and international markets, to support application of advanced technologies as China becomes a source of globally significant innovation.

In these ways, although not in the political change that accompanied sustained modern economic growth elsewhere, China seeks to follow the movement of the established developed countries from middle into high-income status.

Many countries get stuck in that transition and falter for decades in their attempt to enter the high-income group - a circumstance known as the 'middle-income trap' (Eichengreen, Park and Shin 2013).

The transition offers a route to higher incomes for citizens and increasing strategic weight for the nation. Successful transition would see average productivity and income levels in China that are in the range of those in developed countries - an outcome that is possible at some time in the late 2020s if all goes well. By this time, China's population would make it a much larger economy by any measure than the United States or European Union.

This introductory article presents some numbers that provide insights into China's progress towards the goals of the new model of growth. ${ }^{1}$ It is inevitable that there will be noise around assessments of new trends in such a large and diverse economy. Large parts of the eastern coastal provinces in China-Shanghai, Jiangsu, Zhejiang, Fujian, Guangdong and their adjacent special economic areas - already have average living standards within the range of the developed countries. The great metropolis of Beijing also falls within this category, and extends increasing influence over the adjacent province of Hebei and nearby port city of Tianjin. At the same time, there are substantial parts of central and western China, and parts of the northeast, that have large populations of poor people.

China, like Europe only more so, has to be seen as a highly differentiated economy. Any generalisation over the whole country requires qualifications that make it easy to lose the wood in the trees. Here we present the wood, knowing that the reality requires many qualifications.

The general story is one of slowly increasing consumption shares of expenditure and slowly increasing shares of services in expenditure, output and employment. There has been a new tendency towards gradual reduction in inequality as measured by such national measures as the Gini coefficient, after a quarter century of growing inequality. There has been rapid reduction in trade surpluses and the export share of output. Other dimensions of integration into the global economy have risen more quickly - direct foreign investment, especially from China to developing countries, and Chinese export finance. Investment in human capital is increasing rapidly and is already being reflected in rates of patent applications by Chinese firms and other indicators of innovation. There has been a dramatic change in the relationship between economic growth and pressures on the environment.

Data on some of the main dimensions of structural change within the new model of growth is presented in this introductory article.

The second article, by Cai Fang and Xiaojing Zhang, examines the role of reform in maintaining economic growth in contemporary circumstances. China's growth was assisted by a demographic dividend from the beginnings of reform in 1978 until a few years ago. Demographic influences now apply a brake on growth. The labour force can still expand if reform increases labour force participation. The other potential contributor to growth is reform to raise productivity. Success depends on equity in income distribution and confrontation of vested interests that are challenged by change.

The third article, by Huang, Shen and Fu, highlights tension between structural reform and maintenance of growth momentum. The sectors of the economy favoured by the new model of economic growth have done well in recent years. However, a strong focus on meeting growth 
targets this year has supported stronger growth in the old economy, cutting across momentum in the emerging industries. The authors point to risks from financial fragility in the unreformed economy leading to China's first financial crisis since the founding of the People's Republic in 1949.

The fourth article, by Kejun Jiang, ${ }^{2}$ describes the dramatic change in the relationship between economic growth and carbon emissions in China within the new model of growth. At the 2015 Paris Conference, China committed to having greenhouse gas emissions reach a peak and start to head down by or before 2030. Jiang says that coal consumption probably reached its all-time peak in 2013 and carbon emissions possibly in 2014. He describes the rapid growth in renewable energy that has made this possible - making China the world's largest producer of both old (hydro-electric) and new (wind and solar) forms of renewable energy along the way. China has established itself as the world's largest producer and exporter of equipment for electricity generation.

\section{Progress in Macroeconomic Development}

China's economy is now growing at a consistently slower 'new normal' rate than the double-digits of the first decade or so of this century (Figure 1). Annual growth rates were lower only in the macroeconomic crises of the early and late 1980s.

Figure 1 GDP Growth Rates, 1975-2016

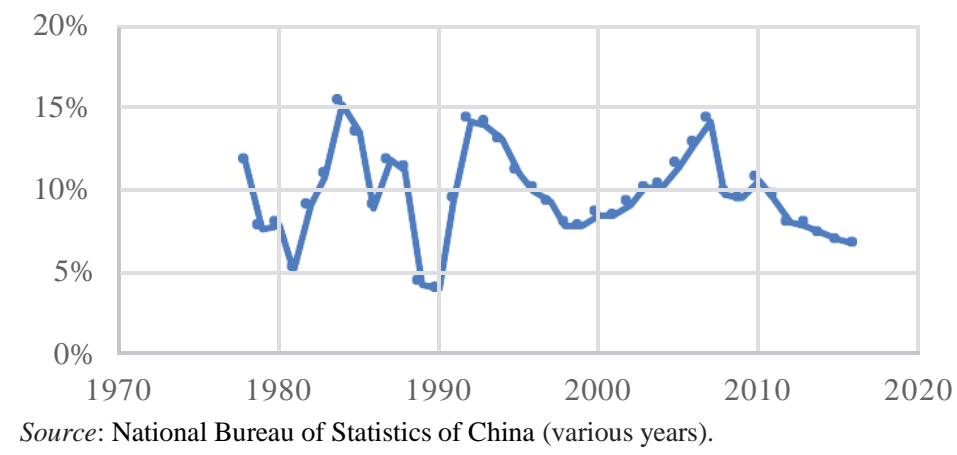

China has made modest progress in recent years in rebalancing the economy towards household consumption and away from fixed capital investment (Figure 2).

Figure 2 Consumption and Investment, 2000-15 


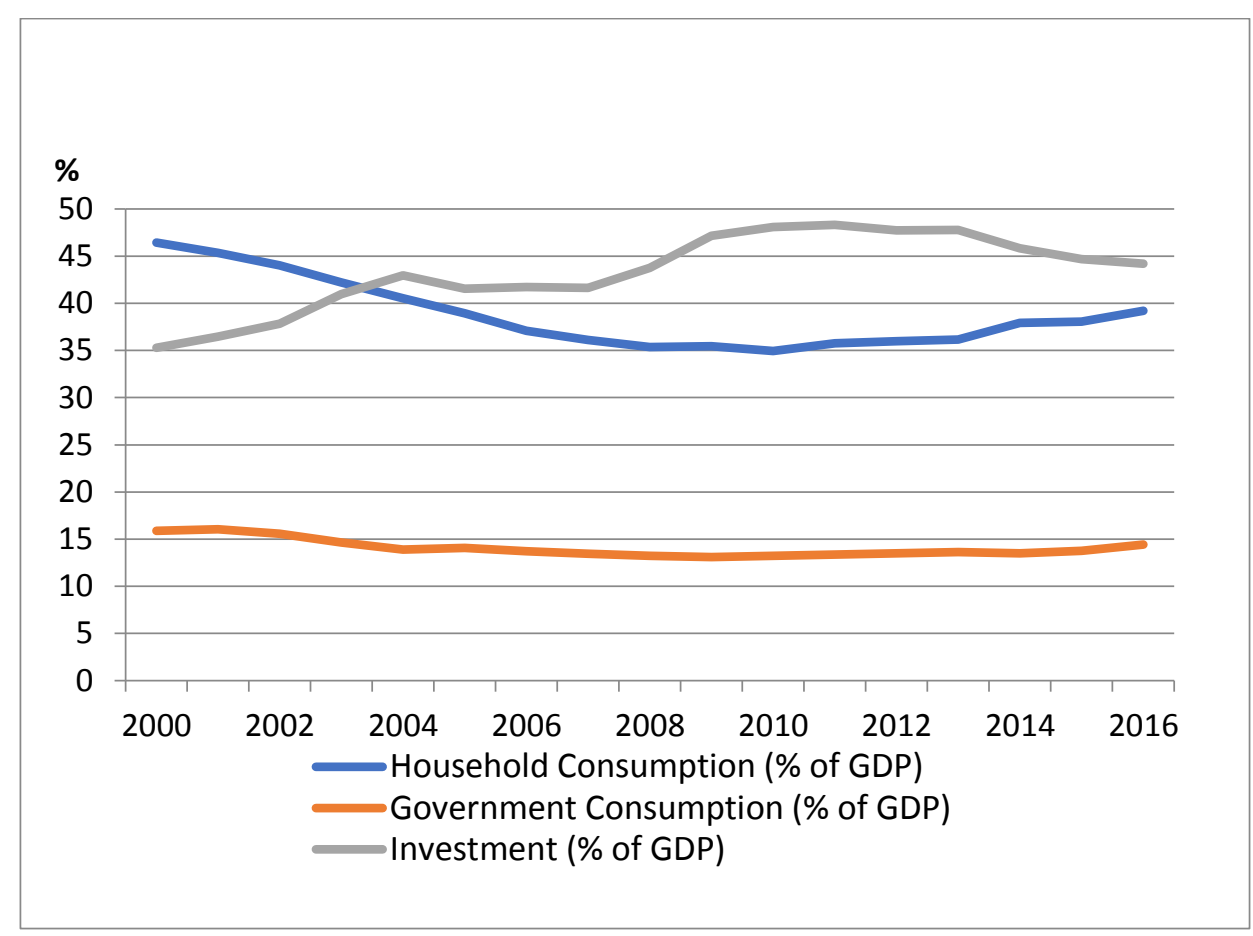

Source: National Bureau of Statistics of China (various years).

As required by China's new model of growth, the tertiary sector has continued to increase its relative size, accounting for 52 per cent of GDP in 2016. Secondary (40 per cent share in 2016) and primary ( 8 per cent) industries have continued their relative decline (Figure 3 ).

China's new growth model allocates a lesser place for exports as a driver of growth. The share of exports in China's GDP rose from about 5 per cent in 1980 to a peak of 37 per cent in 2006 (Figure 4), but has fallen since.

China became the largest trading nation in the world, surpassing the United States, in 2013, and has retained that status since.

\section{Figure 3 Sector Shares in Total GDP, 1978-2016}

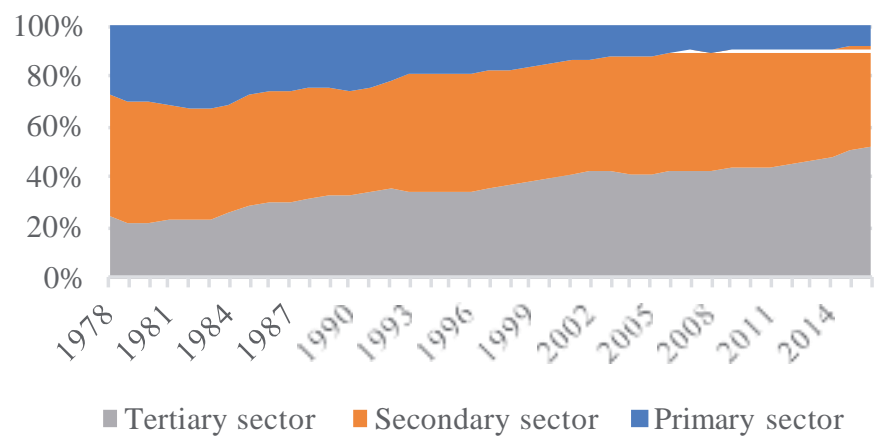

Source: National Bureau of Statistics of China (various years). 
Over the first 30 years of reform, China benefited from a generally favourable international trading environment. The deterioration in international conditions has compounded the domestic changes contributing to a lower export share.

Figure 4 China's Export Share in GDP, 1978-2016

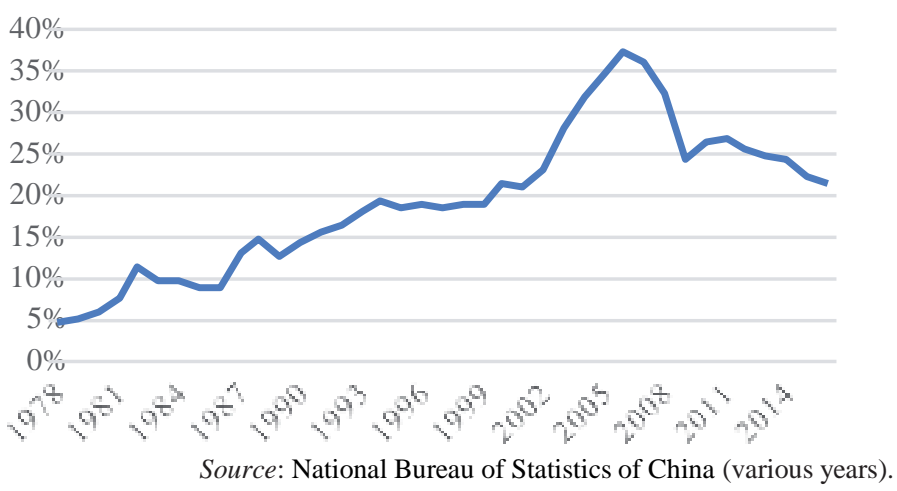

\section{Developments in China's Foreign Economic Relations}

Consistent with the new model of growth, China's trade surpluses have fallen as shares of GDP (Figure 5). China's total foreign reserves have also fallen considerably, to about US $\$ 3$ trillion in 2016. After a long period of real currency appreciation, the pressure through late 2016 and early 2017 was for renminbi (RMB) depreciation against the US dollar. In late 2017, we have seen another reversal, towards growing trade surpluses and currency appreciation again.

Figure 5 Share of China's Trade Surpluses in GDP, 1994-2016

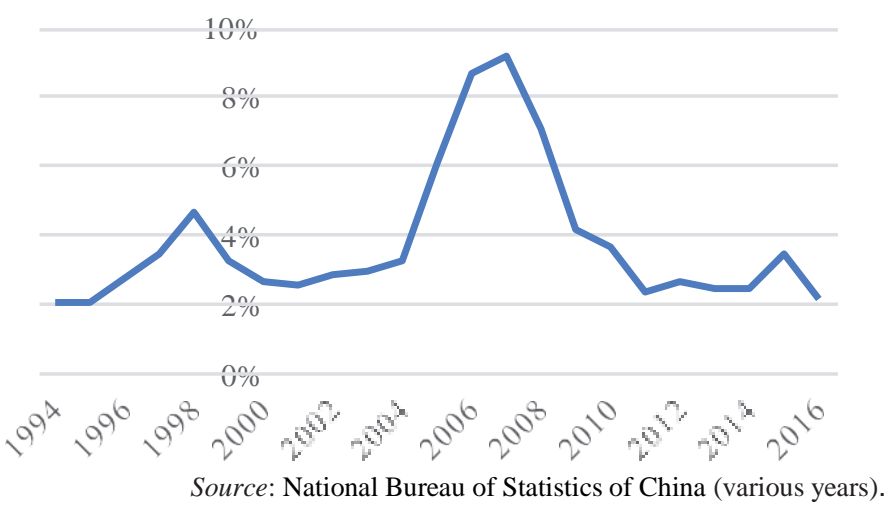

China's share of global trade grew more rapidly than its share of output until the Global Financial Crisis 
(GFC), but more slowly since.

The decline in Chinese trade surpluses has eased global imbalances. This is not without its downside for the global economy. It has diminished a major source of capital for global development - although in recent circumstances of low business investment and higher savings elsewhere-without putting upward pressure on interest rates in other economies. It has also been associated with deceleration of growth in global trade, which has diminished opportunities for other countries to specialise more strongly in exporting goods and services in which they have comparative advantage. Fortunately for global development, structural change in China associated with rising domestic labour costs and appreciation of the real exchange rate has disproportionately increased export opportunities for countries in Southeast Asia, South Asia and the more successful African economies, which are a few rungs below China on the development ladder.

Inbound direct foreign investment has been a major factor in Chinese development since the early years of reform (Figure 6). It accelerated markedly from the early 1990s. Outbound investment grew rapidly from the early years of the current century. It has risen sharply and overtaken inbound investment since 2015. Two-way investment is a major focus of the new model of growth. It can be seen as a successful dimension of the new strategy. Developing countries have been especially important in the growth of outbound investment, receiving some 42 per cent of China's foreign direct investment and making China the largest source of direct investment into developing countries in 2016 (UNCTAD 2016).

\section{Figure 6 Chinese FDI Flows, US\$billion}




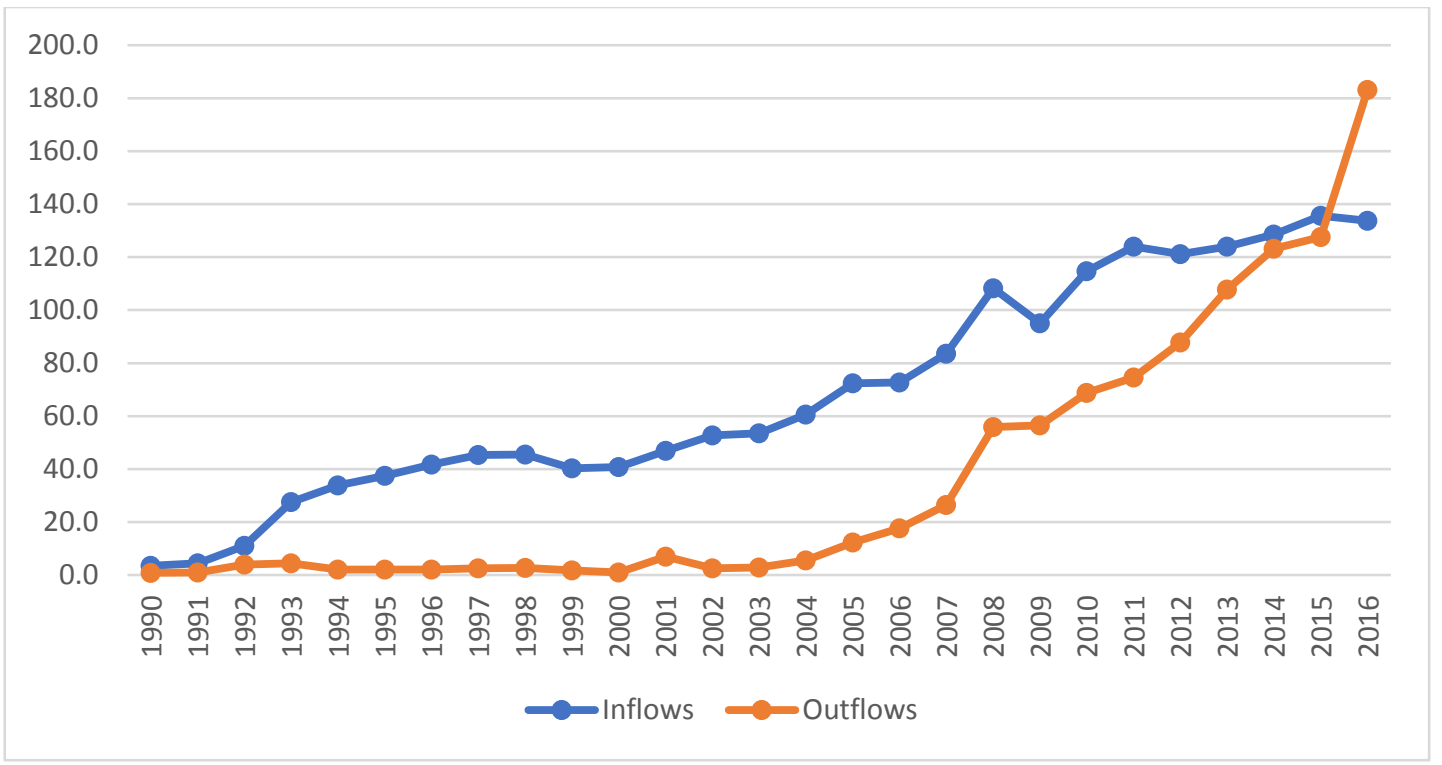

Source: UNCTAD (2016)

Against that economic backdrop, in 2013 China's President Xi Jinping launched his flagship 'Belt and Road Initiative' (BRI). This is an umbrella under which China will institutionalise capital flows to developing countries. Five areas of cooperation are in focus:

(i) coordinating development policies;

(ii) forging infrastructure and facilities networks;

(iii) strengthening investment and trade relations;

(iv) enhancing financial cooperation; and

(iv) deepening social and cultural exchanges.

In dynamic ambition however, the BRI may prove to be less bounded, with President Xi referring to it as the 'project of the century' in mid-2017 (Johnston and Rudyak 2017).

Chinese foreign aid, by contrast, grew rapidly until 2012, but then only slowly. Comparable estimates compiled by Kitano (2017) place China's 2015 net foreign aid at US\$5.4 billion, making it a donor roughly the same size as the Netherlands. Most of China's official funding of activities in developing countries is now used to seed Chinese trade and investment economi opportunity. Under the new 
model of growth, support for Chinese exports has been elevated above development assistance in other forms (Figure 7).

Figure 7 Net Disbursement of China's Foreign Aid, US\$billion

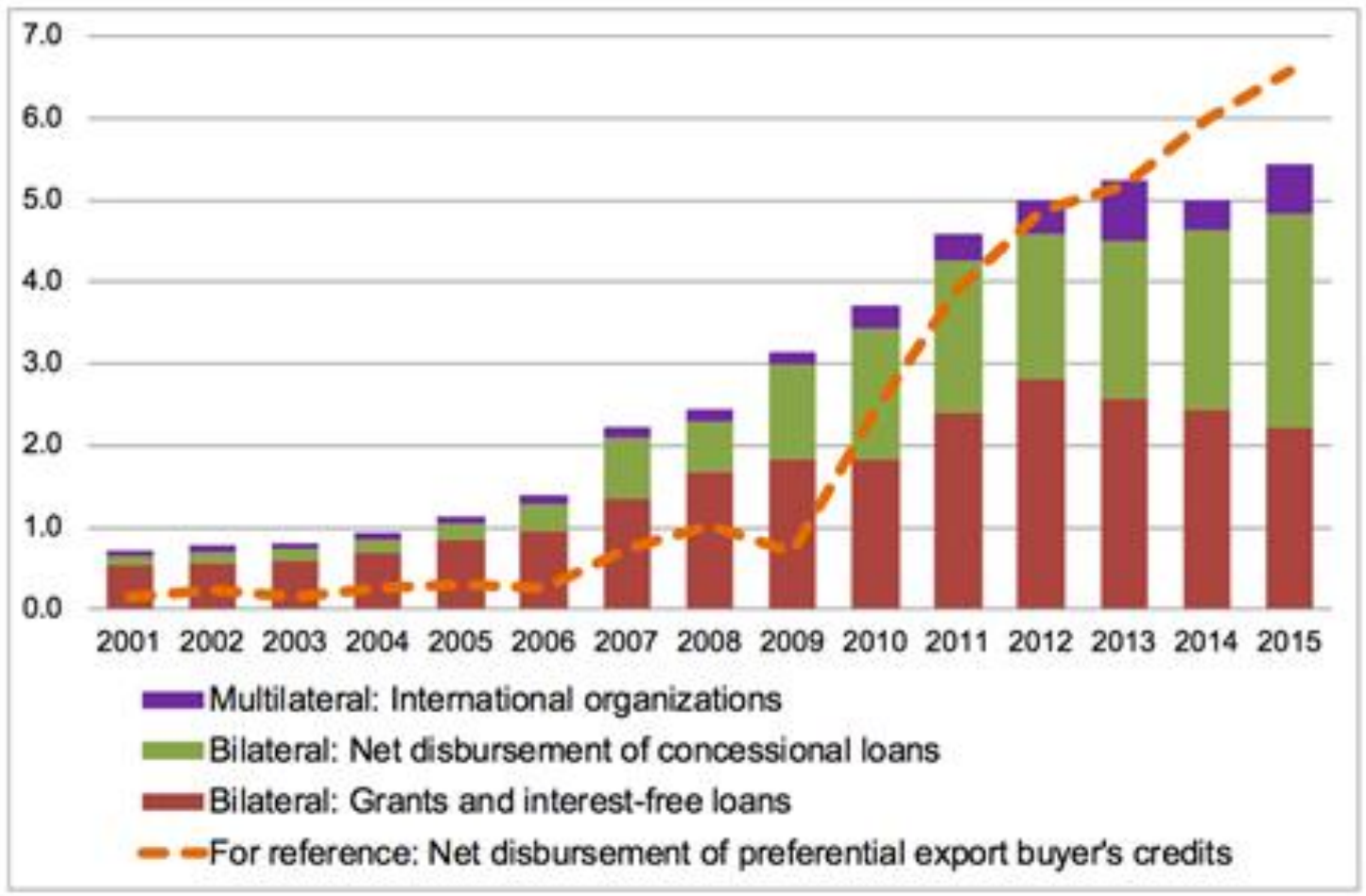

Source: Kitano (2017).

The number of working age people in China has been falling since 2012. Increases in the capital stock continued strongly and contributed an overwhelming proportion of growth in output from 2009 to 2015. The contribution of TFP to China's economic growth fell steadily from 2008. This is explained to some extent by the massive increase in investment through the fiscal stimulus package that was a response to the GFC. The Conference Board (2015) calculations show a modest increase in total factor productivity (TFP) in 2015 after several years of stagnation.

These factors are behind the rising imperative for China to find new ways to boost productivity.

\section{Human Capital}

China has made strides over recent decades in developing its human capital, its innovative capacities and technological potential. Transforming these into growth drivers that allow China to climb from the middle-income trap depends on how 
resources of all kinds are allocated.

Improvements in education and skills can considerably increase the productivity and earnings of labour. The capacity to absorb and use physical capital may be limited by, among other things, investment in human capital. There is a close association between education and the mainsprings of technological progress (Thirlwall and Pacheco-Lopez 2017, p. 210; Jones and Romer 2010, p. 235).

Capital per worker must rise in the new phase of China's development. An effective way of preventing diminishing returns to capital is to increase China's human capital per worker. Towards that goal, China may benefit from its unusual workforce structure, in which human capital is highly skewed in favour of younger workers. This offers new productivity growth potential that is not open to economies where the human capital of older workers is closer to that of younger workforce entrants.

In its review of educational priorities for China in the coming century, the World Bank (1999, p. 9; 2013) reinforces both the positive correlation between education and economic growth and the increasing relevance of education.

Continuous improvement in productivity is expected to become the primary mechanism by which Chinese authorities can promote economic growth through the twenty first century. Education has played an important role in China's economic growth through the reform period. There has been rapid expansion of tertiary education (Figure 8 ). The share of education expenditure in GDP has been rising in recent years, so that it is now approaching the level of developed countries.

Figure 8 University Students Per 100 Population, 1978-2014

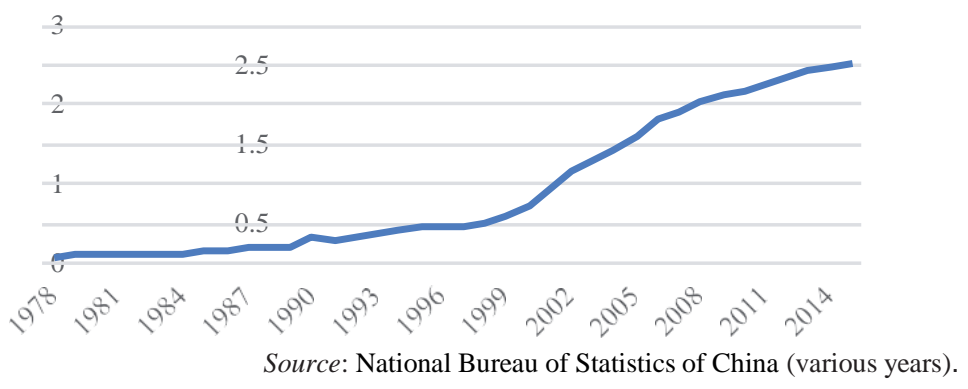

China must do more to improve the quality of education at all levels and also to create an environment in which human capital is effectively 
utilised. China has, for two decades, invested heavily in ensuring that the country is home to some worldclass universities. Peking University and Tsinghua University are now ranked in the top 100 universities worldwide, at 29 and 35, respectively, according to the 2017 Times Higher Education World University Rankings.

Harnessing the benefits of rising human capital through improved institutions (and, thereby, incentives) is another key to sustaining China's future economic growth and contribution to global growth (Glazebrook and Song 2013).

\section{Innovation and Technology}

To encourage innovation, the Chinese Government and Chinese industrial enterprises have invested more and more in research and development (R\&D) (Figure 9).

Figure 9 China's Shares of R\&D and Total Education Expenditure in GDP, 1991-2015

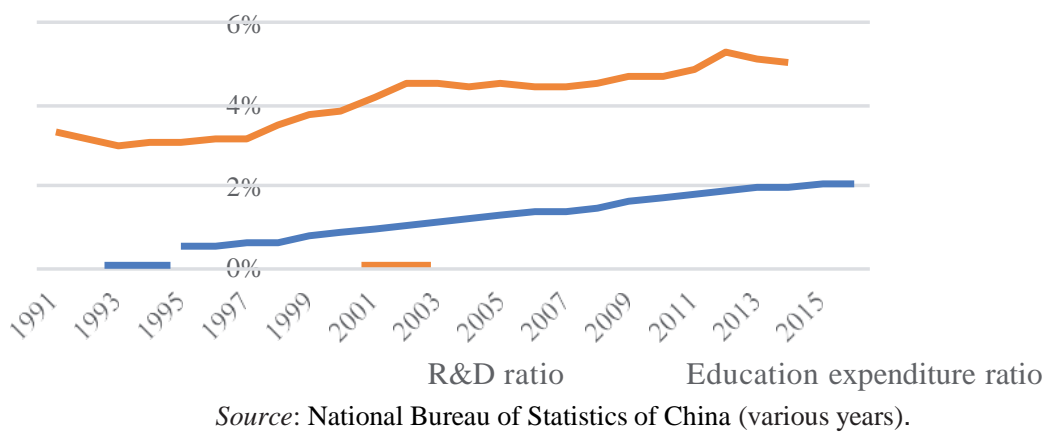

Increased competition, government subsidies and the chance to learn from frontier markets abroad have supported technological improvement. This has led to sharp acceleration in the rate of increase in patent applications (Figure 10). Contributing factors include collaboration between firms and scientific and research institutions, including universities, and the strengthening of incentives.

Figure 10 Number of Patent Applications, 1995-2015 (million) 
invention utility model design

Source: National Bureau of Statistics of China (various years).

Official statements say that efforts will be made to support technological development in China while also enabling continuous learning from other countries. The goal is for China to contribute increasingly to extending the global technological frontiers.

One special focus on innovation and structural change relates to low emissions energy. Table 1 (updated from Garnaut 2016) shows that virtually the whole of the increase in electricity generation since 2013 has come from net zero emissions technologies of hydro-electricity, solar, wind and nuclear. The rate of increase accelerated in 2016 for solar (74 per cent), wind ( 30 per cent) and nuclear ( 28 per cent). Thermal generation picked up in 2016, although much less than the other zero emissions sources. This is consistent with continued reduction in carbon emissions from electricity generation, since much of the increase in thermal energy came from the replacement of low-efficiency by high-efficiency coal plants, and the expansion of gas and biomass generation.

Table 1 Electricity Generation by Source 2010-2016

\begin{tabular}{|c|c|c|c|c|c|c|c|c|c|c|c|c|}
\hline \multicolumn{10}{|c|}{ Quantity (million Mwh) } \\
\hline Year & Total & Thermal & Hydro & Nuclear & Wind & Solar & Total & Thermal & Hydro & Nuclear & Wind & Solar \\
\hline $\mathbf{2 0 1 0}$ & 4,228 & 3,416 & 687 & 75 & 49 & 0 & 14.9 & 13.4 & 20.1 & 6.7 & 78.9 & 73.7 \\
\hline $\mathbf{2 0 1 1}$ & 4,731 & 3,900 & 668 & 87 & 74 & 1 & 11.9 & 14.2 & -2.7 & 16.7 & 49.9 & 459.0 \\
\hline $\mathbf{2 0 1 2}$ & 4,986 & 3,925 & 856 & 98 & 103 & 4 & 5.4 & 0.6 & 28.1 & 12.7 & 39.1 & 412.0 \\
\hline $\mathbf{2 0 1 3}$ & 5,372 & 4,222 & 892 & 112 & 138 & 9 & 7.7 & 7.6 & 4.2 & 14.3 & 34.0 & 125.0 \\
\hline $\mathbf{2 0 1 4}$ & 5,573 & 4,205 & 1,070 & 126 & 156 & 23 & 3.3 & -0.4 & 20.0 & 12.5 & 13.0 & 155.6 \\
\hline $\mathbf{2 0 1 5}$ & 5,605 & 4,097 & 1,114 & 166 & 185 & 38 & 0.6 & -2.6 & 4.1 & 31.7 & 18.6 & 65.2 \\
\hline $\mathbf{2 0 1 6}$ & 5,990 & 4,289 & 1,181 & 213 & 241 & 66 & 6.9 & 4.7 & 6.0 & 28.3 & 30.3 & 73.7 \\
\hline
\end{tabular}

Source: National Bureau of Statistics of China (various years). We thank Derek Cheng for help with the data. 


\section{References}

Conference Board 2015, The Conference Board Total Economy Database, The Conference Board, New York, viewed $\quad 2017$ $<$ https://www.conferenceboard.org/data/economydatabase//>.

Eichengreen, B., Park, D. and Shin, K. 2013, 'Growth slowdowns redux: New evidence on the middleincome trap', National Bureau of Economic Research Working Paper no. w18673, Cambridge, Massachusetts.

Garnaut, R. 2016, 'Mostly slow progress on the new model of growth', in China's New Sources of Economic Growth: Vol. 1, eds R. Garnaut and L. Song, Australian National University, Canberra.

Glazebrook, K. and Song, L. 2013, 'Is China up to the test? A review of theories and priorities for education investment for a modern China', China \& World Economy, vol. 21, no. 4, pp. 56-78.

Johnston, L. A. and Rudyak, M. 2017, 'China's "innovative and pragmatic" foreign aid: Shaped by and now shaping globalisation', in China's New Sources of Economic Growth: Vol. 2, L. Song et.al. eds Australian National University, Canberra.

Jones, C. I. and Romer, P. M. 2010, 'The new Kaldor facts: Ideas, institutions, population, and human capital', American Economic Journal: Macroeconomics, vol. 2, no. 1, pp. 224-45.

Kitano, N. (2016), Estimating China's Foreign Aid II: 2014 Update, JICA-RI Working Paper No. 131, June, JICA Research Institute, Tokyo, viewed September $2017<w w w . j i c a$. go.jp/jicari/publication/workingpaper/wp_131.html>.

National Bureau of Statistics of China (various years), China Statistical Yearbook, China Statistics Press, Beijing.

Song, L., Garnaut, R., Cai, F. and Johnston, L. (eds) (2017), China's New Sources of Economic Growth: Vol. 11, ANU Press, Canberra and Beijing. 
Thirlwall, A. P. and Pacheco-Lopez, P. 2017, Economics of Development: Theory and Evidence, Palgrave Macmillan, London.

United Nations Conference on Trade and Development (UNCTAD) 2016, World Investment Report 2016: Investor Nationality-Policy Challenges, United Nations Publications, New York.

World Bank 1999, Strategic Goals for Chinese Education in the 21st century, Report no. 18969CHA, World Bank, Washington, DC, <documents.worldbank.org/curated/en/20395146 $8768863829 /$ Strategic-goals-for-Chineseeducation-in-the-21st-century>.

World Bank 2013, China 2030: Building a Modern, Harmonious, and Creative Society, Report no. 76299, World Bank, Washington, DC, <http://documents.worldbank.org/curated/en/781 101468239669951/China-2030-building-amodern-harmonious-and-creative-society>

1 Much of the material in these papers is drawn from or updated from versions of earlier and more detailed papers in Song et al. (2017), ANU press; and will be published in Chinese by China Social Sciences Press, Chinese Academy of Social Sciences, Beijing, 2018.

2 Jiang's article provides details on the expansion of renewables generation. 